\title{
Seasonal movements and distribution of Dungeness crabs Cancer magister in a glacial southeastern Alaska estuary
}

\author{
Robert P. Stone*', Charles E. O'Clair \\ Auke Bay Laboratory, Alaska Fisheries Science Center, National Marine Fisheries Service, National Oceanic \\ and \\ Atmospheric Administration, 11305 Glacier Highway, Juneau, Alaska 99801, USA
}

\begin{abstract}
The movements of 10 female and 8 male adult Dungeness crabs, Cancer magister (Dana, 1852), were monitored biweekly to monthly with ultrasonic biotelemetry for periods ranging from 73 to $555 \mathrm{~d}$. Female and male crabs had different seasonal patterns of habitat use, depth distribution, and activity. The general pattern for female crabs was: (1) a relatively inactive period between November and mid-April at depths below $20 \mathrm{~m}$; ovigerous crabs were typically buried during this period in a dense aggregation; (2) abrupt movement into shallow water $(<8 \mathrm{~m})$ in late April and residence there until early June; this movement was coincident with the spring phytoplankton bloom and initiation of larval hatching; (3) increased activity beginning in July with movement back to deeper water, presumably to forage. Females that molted prior to oviposition did so in June and July. Male crabs occupied deep water $(>40 \mathrm{~m}$ ) from November to April, then concentrated in shallow water $(<25 \mathrm{~m})$, segregated from females, until late July. Males were most active in late summer and moved into deeper water $(>30 \mathrm{~m})$ near the mouth of the cove in fall. The range of depths were -0.5 to $-61.3 \mathrm{~m}$ for females and +0.1 to $-89.0 \mathrm{~m}$ for males. Female crabs showed fidelity to the head of the cove and typically ranged only $1.5 \mathrm{~km}$ from there. Male crabs, however, moved up to $7.2 \mathrm{~km}$ from the head of the cove, but did not move close to the nearest established population of Dungeness crabs $9.6 \mathrm{~km}$ distant. The discrete population of adult Dungeness crabs in Fritz Cove may be representative of most Dungeness crab populations inhabiting shallow embayments of the coastal fjord system of southeastern Alaska.
\end{abstract}

KEY WORDS: Dungeness crab $\cdot$ Biotelemetry $\cdot$ Essential habitat $\cdot$ Migration

Resale or republication not permitted without written consent of the publisher

\section{INTRODUCTION}

The Dungeness crab, Cancer magister (Dana, 1852), ranges from the Pribilof Islands, Alaska to Magdalena Bay, Mexico (Jensen \& Armstrong 1987) and is exploited in commercial and recreational fisheries throughout most of this range. However, Dungeness crab populations do not show the same pattern of distribution throughout the species' range. In the southern part of the range, the coastline is more uniform and less frequently indented with bays and estuaries, and Dunge-

\footnotetext{
*E-mail: bob.stone@noaa.gov
}

ness crabs inhabit more of the outer coast. In the northern part of the range, Dungeness crabs predominately inhabit bays and fjord-type estuaries. Distinct inlandwater and outer coast populations are thought to occur in some areas of Washington and British Columbia (Orensanz \& Gallucci 1988, DeBrosse et al. 1990, Dinnel et al. 1993). In northern California, some outer coast populations may be discrete and geographically isolated from one another (Diamond \& Hankin 1985).

Oceanographic conditions vary greatly throughout the $3900 \mathrm{~km}$ latitudinal range of the Dungeness crab, and these conditions can affect the timing of life history events and rates of biological processes. Latitudinal variation exists in the timing of egg extrusion, larval 
hatching, mating, and ecdysis in adults (Cleaver 1949, Butler 1956, Gotshall 1978, Wild 1980, Diamond \& Hankin 1985, Sulkin \& McKeen 1996, Hankin et al. 1997). In general, the reproductive schedules for crabs from the southern end of the range occur earlier in the year than those from northern areas. Rates of embryonic development and larval growth also seem faster in the south. Water temperature affects the rates of egg and larval development (Wild 1980, Shirley et al. 1987) and growth of various instars (Orensanz \& Gallucci 1988, Kondzela \& Shirley 1993). Local variability within regions also occurs in the timing of these life history events, and this variability has been attributed to differences in water temperature between inshore and offshore areas (Sulkin \& McKeen 1996). Because many fisheries are scheduled to avoid fishing activity during periods of high vulnerability and sensitive life history events (e.g., ecdysis and mating), knowledge of the local timing of these events is critical for effective management.

The magnitude of migrations made by some species of crabs may depend on local bathymetry and the spatial distribution of essential habitat (Wallace et al. 1949, Stone et al. 1992). We hypothesized that migrations made by Dungeness crabs in the deep fjord-type estuaries of southeastern Alaska are more restricted than those by crabs in oceanic environments. The objectives of this study were to determine the seasonal movements and habitat use of adult Dungeness crabs in 1 southeastern Alaska estuary and to relate them to life history events. We also investigated the relationship between these life history events and oceanographic conditions.

\section{MATERIALS AND METHODS}

This study was conducted in Fritz Cove, $11 \mathrm{~km}$ north of Juneau, Alaska (Fig. 1), which has a water surface area of about $8 \mathrm{~km}^{2}$ at mean higher high water. Fritz Cove is a small estuary located off a system of large, fjord-type channels. The deepest part of the cove is greater than $100 \mathrm{~m}$; about $12 \%$ of the cove is intertidal habitat. The cove is strongly influenced by several freshwater watersheds that empty into Gastineau Channel, including the glacial Mendenhall River and the clearwater Fish Creek (Fig. 1). A strong buoyant plume estuarine front (Largier 1992) is prominent, especially along the northern portion of the cove, between June and October. In general, sub-surface currents are weak, non-directional, and tidally derived (US Department of the Interior 1966). Most of the subtidal area of the cove deeper than 20 m below mean lower low water (MLLW) is covered with glacial silt. The cove is closed to commercial fishing for Dunge-

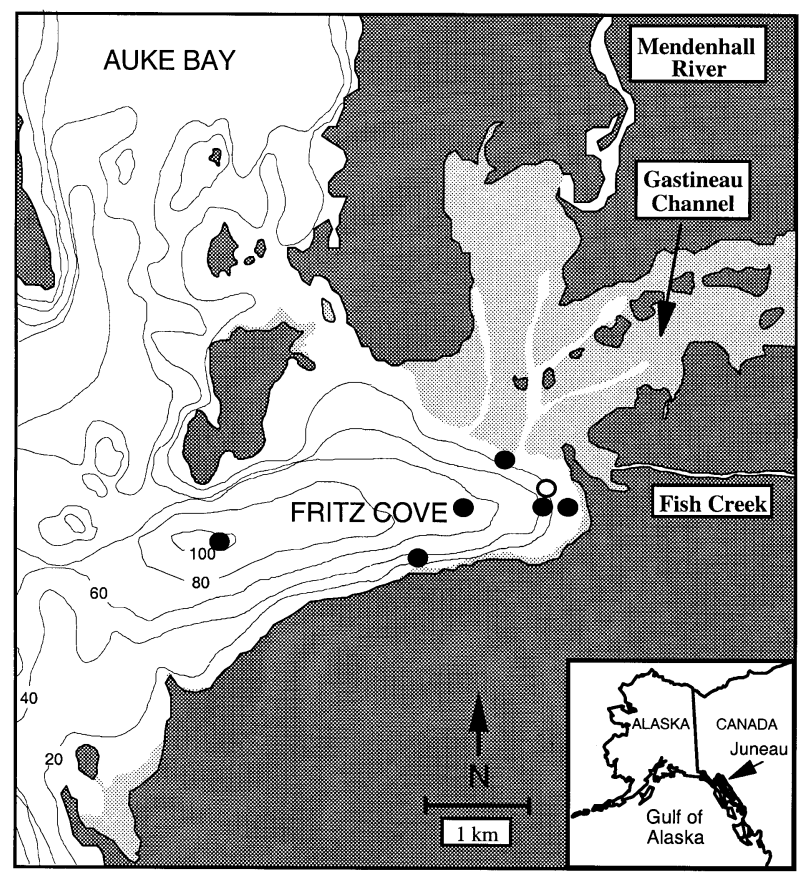

Fig. 1. Study area at Fritz Cove, near Juneau, Alaska, where the movements of adult Cancer magister fitted with ultrasonic transmitters were monitored. (O) Location of area where crabs were initially captured; (•) stations where oceanographic profiles of the water column were collected. Depth contours are in meters

ness crab but is used extensively for recreational crabbing.

Female and male Cancer magister were collected by SCUBA divers on 8 November and 10 October 1989 respectively, and brought back to the laboratory for tagging. All crabs were collected near the head of the cove (Fig. 1) at a depth of about $20 \mathrm{~m}$, and upon release were returned to the bottom at the collection site by divers to minimize disorientation associated with release in an unfamiliar area (Powell 1964). Ultrasonic tags with a 2 yr life expectancy were attached to 5 female and 5 male crabs. Two additional females were tagged on 13 April and 3 additional females were tagged on 18 May, 26 June, and 11 July 1990 when divers recovered derelict tags (i.e., detached from live crabs). Two additional males were tagged on 13 April 1990 and 1 male was tagged on 11 July 1990. Female crabs ranged from 143.9 to $163.2 \mathrm{~mm}$ carapace width (CW) $(\bar{x}=153.0 \mathrm{~mm})$ and weighed (wet weight) between 531 and $773 \mathrm{~g}(\bar{x}=676 \mathrm{~g})$. Male crabs ranged from 157.8 to $191.8 \mathrm{~mm} \mathrm{CW}(\bar{x}=179.7 \mathrm{~mm})$ and weighed between 659 and $1182 \mathrm{~g}(\bar{x}=976 \mathrm{~g})$. All female crabs were ovigerous and had full or near-full egg clutches. Only crabs in good physical condition (i.e., no missing appendages or gross evidence of disease) were tagged. 
Tags were attached directly to the carapace in the cervical groove between the gastric and cardiac regions with nontoxic SeaGoin' Poxy Quik 5 min epoxy putty. Each transmitter (Sonotronics Model CHP-87) had a unique aural code and a range of about $2 \mathrm{~km}$. The tags were $105 \mathrm{~mm}$ long, $16 \mathrm{~mm}$ in diameter and weighed $12 \mathrm{~g}$ in water $(<2.3 \%$ of the total body weight for female crabs and $<1.8 \%$ for male crabs). Crabs were held in flow-through aquaria in the laboratory for at least $12 \mathrm{~h}$ prior to release to ensure tag adherence to the carapace.

Positions of the crabs were 'fixed' approximately monthly through winter and then biweekly thereafter. Movements were monitored by surveying the cove in a small boat. To locate crabs we used an ultrasonic receiver (Sonotronics Model USR-4D) and directional hydrophone (Sonotronics Model DH-2) with a beam width of plus/minus $6^{\circ}$ at half-power points. A small float was deployed after the boat was positioned over a crab. The boat was maintained at this float while its position was fixed by measuring angles between 3 markers on shore with a beam-converging sextant used as a pelorus (O'Clair et al. 1990). We estimated an error of $\pm 8.8 \mathrm{~m}$ associated with this 'mark-on-top' method by calculating the mean distance between fixes $(n=27)$ for stationary derelict tags.

Depth was measured with a Hummingbird Model 4080D depth finder and is reported relative to MLLW. A Seabird Electronics Seacat Profiler was used to collect temperature, salinity, density (sigma-t), and dissolved oxygen profiles of the water column at 6 stations throughout the cove. Physical oceanographic variables at depths occupied by crabs were estimated from the profile at the nearest station to each crab. Divers used SCUBA and a submersible receiver/ hydrophone (Sonotronics Model USR-88) to recover derelict transmitters and to periodically observe tagged crabs within diving depth (<35 m). In situ observations on tagged and untagged crabs included data on sediment type, crab associations, molting or mating behavior, oviposition, and the condition of the egg mass for ovigerous crabs (evidence of hatching, approximate degree of development).

Benthic sediment-core samples were collected from the top $10 \mathrm{~cm}$ of bottom sediment by SCUBA divers. Sediments were wet-sieved and graded using the Wentworth scale (Holme \& McIntyre 1971).

All means of time-series variables (i.e., activity rate, depth, oceanographic data) are presented as the mean $\pm 1 \mathrm{SE}$ of the mean. All movements were charted with a microcomputer design and drafting program (Autodesk 1988). The home range was estimated by the mini- mum-convex polygon method (Worton 1987). Activity rate was calculated as distance moved in meters divided by time in days between successive observations.

\section{RESULTS}

The movements of 10 female and 8 male adult Cancer magister were monitored for periods ranging from 73 to 555 d (Table 1, Fig. 2). Female crabs were monitored for between 73 and $244 \mathrm{~d}$ and male crabs were monitored for between 75 and 555 d (Table 1, Fig 2). Initially, we intended to monitor the movement of crabs through 1 complete reproductive cycle (12 mo); when biweekly tracking was suspended after $1 \mathrm{yr}$, however, only 3 of the original males and none of the original females had active transmitters attached. The signal from only 1 transmitter was lost during the entire study period (Table 1); this crab either moved out of the study area or the transmitter failed.

Female and male crabs had different seasonal patterns of habitat use, depth distribution, and activity. Female crabs followed a general pattern of seasonal movement and habitat use that could be divided into 3 phases: (1) a relatively inactive period between November and mid-April at depths below $20 \mathrm{~m}$, when ovigerous crabs were usually buried in a dense aggregation; (2) abrupt movement into shallow water $(<8 \mathrm{~m})$ in late April and residence there until early June; onset of this movement was coincident with the spring phytoplankton bloom, and larvae hatched mostly during the latter part of this period; (3) increased activity beginning in July with gradual movement into deeper water.

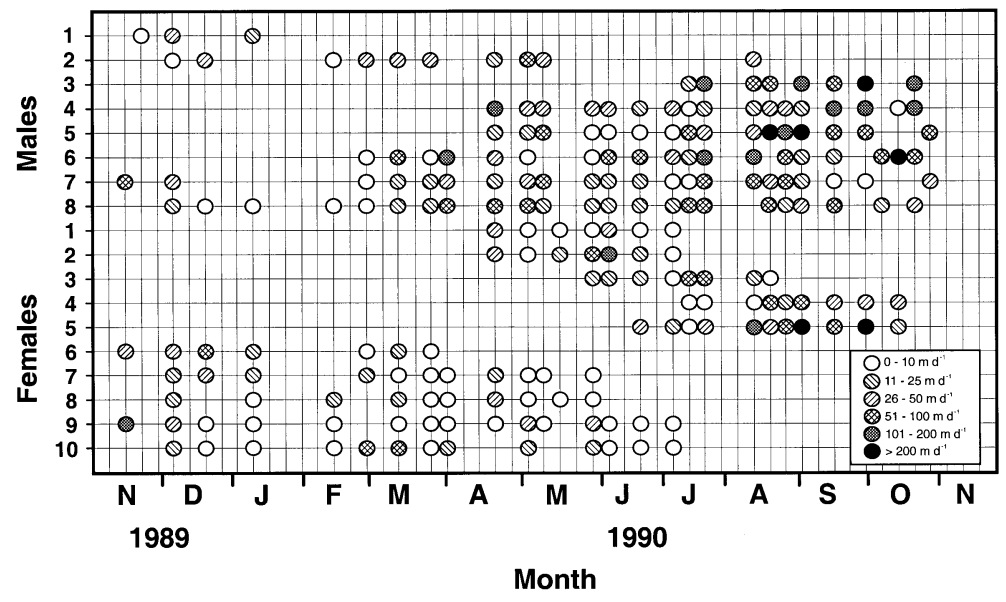

Fig. 2. Cancer magister. Tracking records for 18 crabs fitted with ultrasonic transmitters. Each symbol indicates when an individual crab's position was fixed. Crab numbers for females and males on ordinate correspond to order the crabs are listed in Table 1. Pattern of each circle indicates the activity rate (mean movement per day, $\mathrm{m} \mathrm{d}^{-1}$ ) for the period from the proceeding position fix to the present position fix 
Table 1. Cancer magister. Carapace width (CW), date of release, duration of tracking, home range (measured with the minimum convex polygon, MCP, method), and fate of 10 female and 8 male Dungeness crabs monitored with ultrasonic biotelemetry in Fritz Cove, near Juneau, Alaska. nm: not measured because of small sample size of position fixes $(\mathrm{n}=4)$

\begin{tabular}{|c|c|c|c|c|}
\hline $\mathrm{CW}(\mathrm{mm})$ & Release date & Duration (d) & $\operatorname{MCP}\left(\mathrm{m}^{2}\right)$ & Fate of crab \\
\hline \multicolumn{5}{|c|}{ Female crabs } \\
\hline 155.4 & $13 / 4 / 90$ & 73 & 65012 & Molted on $15 / 7 / 90$ at $-16.4 \mathrm{~m}$ \\
\hline 163.2 & $13 / 4 / 90$ & 73 & 189189 & Molted on $11 / 7 / 90$ at $-8.9 \mathrm{~m}$ \\
\hline 143.9 & $18 / 5 / 90$ & 96 & 339335 & At large $\mathrm{e}^{\mathrm{a}}$ \\
\hline 155.2 & $11 / 7 / 90$ & 98 & 185855 & At large $^{a}$ \\
\hline 151.8 & $26 / 6 / 90$ & 113 & 1341330 & At large $^{\mathrm{a}}$ \\
\hline 159.4 & 9/11/89 & 141 & 407290 & Derelict tag-unknown cause \\
\hline 159.5 & 9/11/89 & 208 & 603045 & Molted on $5 / 6 / 90$ at $-5.5 \mathrm{~m}$ \\
\hline 144.7 & 9/11/89 & 210 & 151401 & Molted on $7 / 6 / 90$ at $-5.9 \mathrm{~m}$ \\
\hline 146.8 & 9/11/89 & 244 & 279108 & Molted on $15 / 7 / 90$ at $-21.0 \mathrm{~m}$ \\
\hline 149.9 & $9 / 11 / 89$ & 244 & 444479 & Molted on $11 / 7 / 90$ at $-18.3 \mathrm{~m}$ \\
\hline \multicolumn{5}{|l|}{ Male crabs } \\
\hline 191.8 & $30 / 10 / 89$ & 75 & $\mathrm{~nm}$ & Signal lost \\
\hline 182.2 & $30 / 10 / 89$ & 200 & 1138937 & Octopus predation \\
\hline 180.0 & $11 / 7 / 90$ & 212 & 3186250 & At large ${ }^{a}$ \\
\hline 157.8 & $13 / 4 / 90$ & 301 & 1326617 & Molted on $21 / 2 / 91$ at $-6.6 \mathrm{~m}$ \\
\hline 178.7 & $13 / 4 / 90$ & 373 & 2199662 & Crab and tag recovered \\
\hline 178.9 & $30 / 10 / 89$ & 446 & 10503694 & Molted on $18 / 1 / 91$ at $-39.9 \mathrm{~m}$ \\
\hline 185.2 & $30 / 10 / 89$ & 446 & 3290968 & At large ${ }^{a}$ \\
\hline 182.6 & $30 / 10 / 89$ & 555 & 4603538 & At large $^{a}$ \\
\hline
\end{tabular}

During winter, ovigerous female crabs generally remained near the head of the cove in a well-defined area at 20 to $25 \mathrm{~m}$ depth (Fig. 3A). Dive observations indicated that ovigerous females in dense aggregations were often completely buried in a mixture of moderately sorted fine sand and silt (median particle size $=138 \mu m_{i}$ Table 2) on a moderate slope (18 to $33 \%$ ). Several crabs, however, made sporadic forays of less than $700 \mathrm{~m}$ during this 6 mo period (Fig. 3A).

During late April, female crabs moved abruptly into shallow water $(<8 \mathrm{~m})$ areas near the head of the cove (Fig. 3B). The onset of this movement was coincident with the spring phytoplankton bloom. Diver observations of ovigerous crabs indicated that larvae hatched throughout this period but mostly during the latter part of the period. By late June, all female crabs had matted setae on their pleopods, indicating recent larval hatching. Movements in shallow water were restricted.

By early June, many females had increased activity and began to move to deeper water (Fig. 3C). We presume that this movement to deeper water was associated with increased foraging or dispersal to molt and mate. Females that molted prior to egg extrusion did so between early June and mid-July at depths between 6 and $21 \mathrm{~m}$ (Table 1, Fig. 3C).

Male crabs occupied deep water $(>40 \mathrm{~m})$ from November to April (Fig. 4A), then concentrated in shallow waters $(<25 \mathrm{~m})$, typically segregated from females, until late July (Fig. 4B). Diver observations made during this shallow-water phase indicated that males were loosely aggregated on the slope habitat and were shallowly buried in the sediment. Males were very active in late summer and moved into deeper water (>30 m) near the mouth of the cove, where 2 of the tagged crabs molted in January and February (Table 1, Fig. 4C).

Female crabs had smaller home ranges and moved shorter distances from the release site near the head of the cove than male crabs. Female crabs had home ranges of 0.65 to $1.34 \mathrm{~km}^{2}\left(\bar{x}=0.40 \mathrm{~km}^{2}\right)$, whereas

Table 2. Particle-size analysis of sediment collected where ovigerous Cancer magister formed dense buried aggregations in Fritz Cove. Sediments were collected at $21.6 \mathrm{~m}$ below MLLW and graded using Wentworth scale

\begin{tabular}{|lccc|}
\hline Sediment type & $\begin{array}{c}\text { Size } \\
(\mu \mathrm{m})\end{array}$ & $\begin{array}{c}\text { Weight } \\
(\mathrm{g})\end{array}$ & $\begin{array}{c}\text { Composition } \\
(\%)\end{array}$ \\
\hline Pebble & $>4000$ & 0.0 & 0.0 \\
Granule & $4000-2000$ & 0.0 & 0.0 \\
Very coarse sand & $2000-1000$ & $1.7^{\mathrm{a}}$ & 0.5 \\
Coarse sand & $1000-500$ & 0.5 & 0.1 \\
Medium sand & $500-250$ & 16.5 & 4.9 \\
Fine sand & $250-125$ & 168.1 & 49.8 \\
Very fine sand & $125-63$ & 76.1 & 22.5 \\
Silt & $<63$ & 74.7 & 22.2 \\
aConsisted of approx. 67\% bivalve shell fragments \\
\hline \multicolumn{4}{|l}{} \\
\hline
\end{tabular}



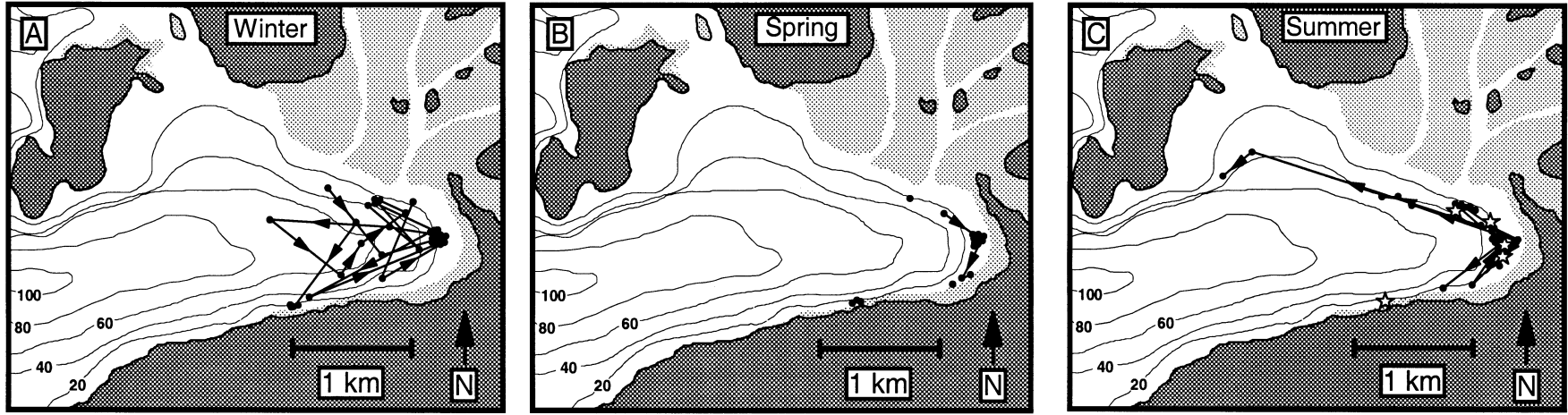

Fig. 3. Cancer magister. Areas of distribution and movement patterns of females fitted with ultrasonic transmitters. Arrows indicate large-scale movement. (A) Distribution from November 1989 to mid-April 1990; (B) distribution from late April through early June 1990; (C) distribution from mid-June through August 1990. Star symbols $(n=5)$ show where female crabs molted. Depth contours are in meters

males had home ranges between 1.14 and $10.5 \mathrm{~km}^{2}$ $\left(\bar{X}=3.75 \mathrm{~km}^{2}\right)$ (Table 1). Female crabs moved between 0.38 and $4.23 \mathrm{~km}$ from the head of the bay where they were tagged, and none left the bay (Fig. 3). Male crabs migrated between 2.13 and $7.24 \mathrm{~km}$ from the head of the bay but all either molted near the entrance of the bay or returned to the bay in spring (Fig. 4).

The mean depth occupied by females was shallower than that occupied by males during each month, except when both groups occupied shallow water during June and July (Fig. 5A). Female crabs occupied depths from -0.5 to $-61.3 \mathrm{~m}$, whereas male depths ranged from +0.1 to $-89.0 \mathrm{~m}$.

Both female and male crabs had low activity rates during winter (through March), but activity rate increased sharply in spring when crabs moved into shallow water (Figs. $2 \& 5 \mathrm{~B}$ ). Female crabs were relatively inactive during the period of larval hatch, but activity increased again during summer when females presumably foraged at greater depths (Fig. 5B). Male crabs had maximum activity in early April when they moved into shallow water, followed by a relatively quiescent period while in shallow water through June (Fig. 5B). Males were very active between July and October (Figs. 2 \& 5B).

Because the oceanographic variables measured during this study varied with depth, and both female and male crabs had similar patterns of depth distribution (Fig. 5A), these variables did not differ greatly for the 2 groups (Fig. 6). Mean water temperature of areas occupied by females ranged from $3.1^{\circ} \mathrm{C}$ during early March to $10.0^{\circ} \mathrm{C}$ during late August (Fig. 6A). Males occupied areas with mean water temperatures ranging from $3.0^{\circ} \mathrm{C}$ during early March to $9.5^{\circ} \mathrm{C}$ in July (Fig. 6A). Individual crabs occupied water temperatures between 2.7 and $12.2^{\circ} \mathrm{C}$.
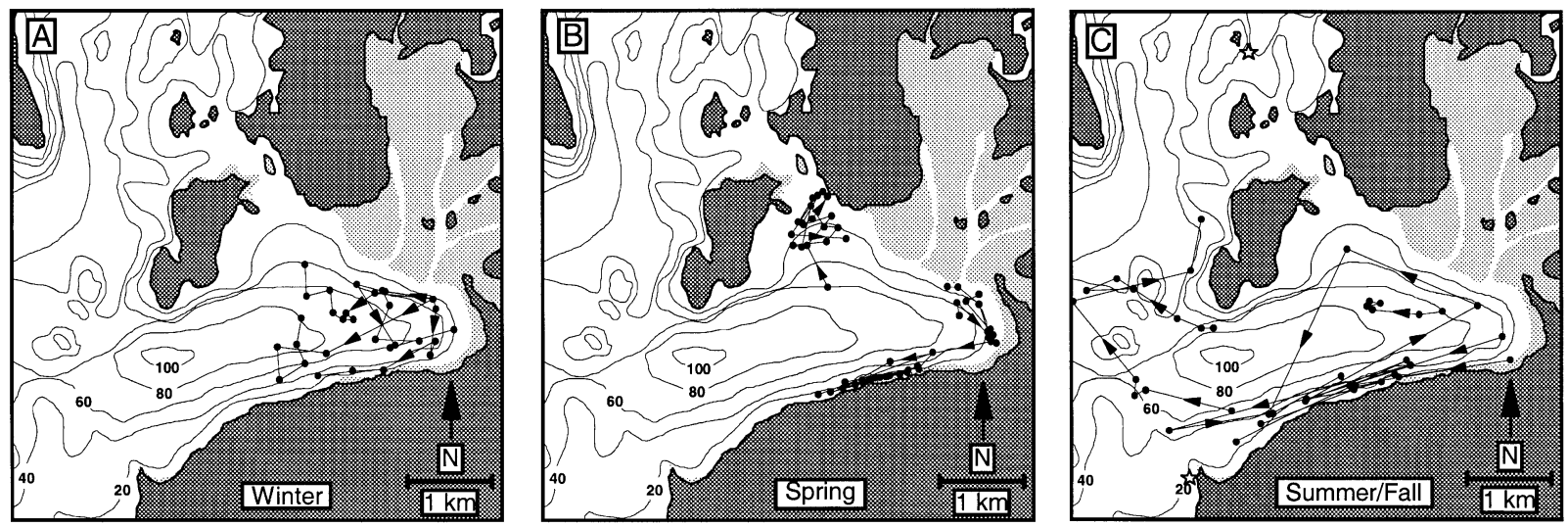

Fig. 4. Cancer magister. Areas of distribution and movements of males fitted with ultrasonic transmitters. Arrows indicate largescale movement. (A) Distribution from November 1989 through March 1990; (B) distribution from April through late July 1990; (C) distribution from late July through October 1990. Star symbols $(n=2)$ show where male crabs molted. Depth contours are in meters 

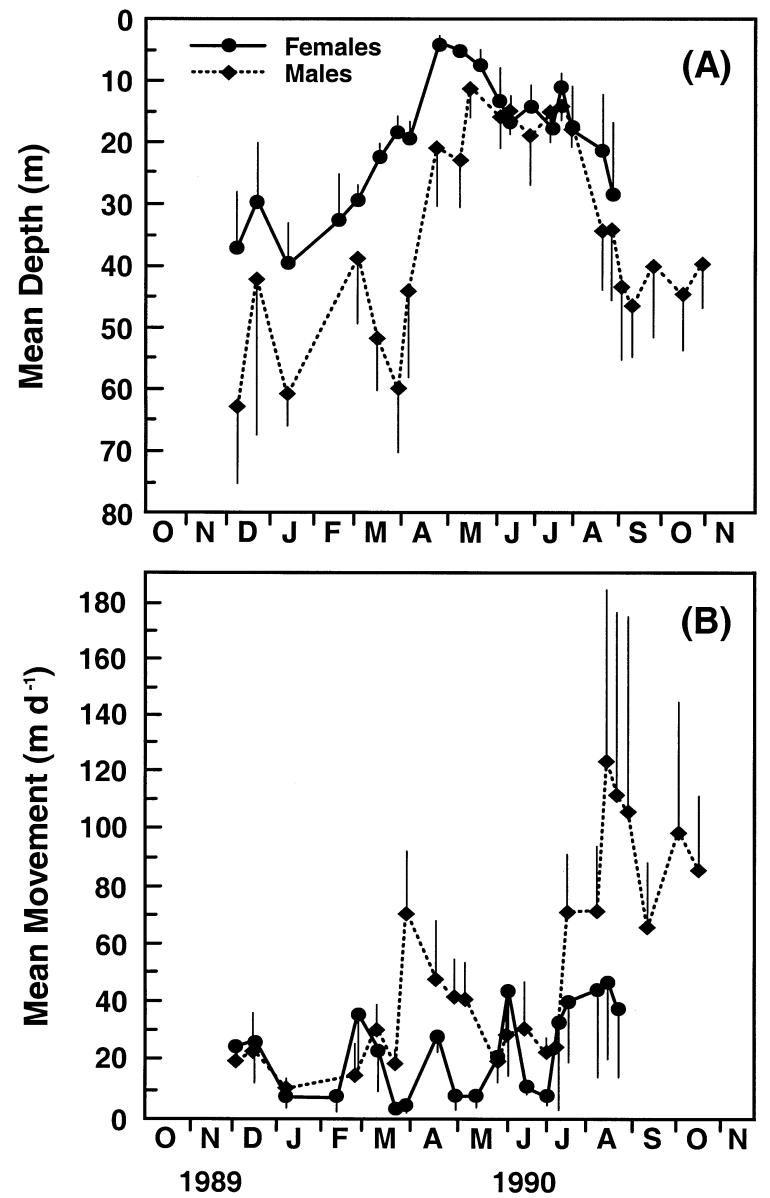

Fig. 5. Cancer magister. (A) Mean depth and (B) activity rate (mean movement per day, $\mathrm{m} \mathrm{d}^{-1}$ ) for females $(-1$ standard error of the mean, SEM) and males (+1 SEM) fitted with ultrasonic transmitters between November 1989 and 1990

The mean salinity of areas occupied by females ranged from 26.5 to 31.3 compared with 24.8 to 31.5 in areas occupied by males (Fig. 6B). Crabs were exposed to the lowest salinity in July, when they occupied shallow water inundated with fresh water from streams, and were exposed to the highest salinity in late March before they moved into shallow water. Individual female crabs occupied areas where salinity was 21.0 to 31.8 , whereas males occupied areas where salinity was 18.3 to 31.9 .

Both groups of crabs occupied areas of fairly welloxygenated water throughout the year (Fig. 6C). In general, shallow water had higher dissolved oxygen (DO) concentrations, and this was especially evident beginning in April during the spring phytoplankton bloom, when both groups of crabs moved into shallowwater areas. Larvae began to hatch during this period, as evidenced by in situ observations of females with matted pleopodal setae and observations on collected crabs held in the laboratory. We suspect that the sharp drop in DO in early June (Fig. 6C) was due to the rapid settlement of senescent phytoplankton from shallow water. Mean DO concentrations of areas occupied by female crabs ranged from $5.1 \mathrm{ml} \mathrm{l}^{-1}$ (69\% saturation) in December to $7.8 \mathrm{ml} \mathrm{l}^{-1}(118 \%$ saturation) in July (Fig. 6C). Individuals occupied areas ranging from 4.4 (62\% saturation) to $8.7 \mathrm{ml} \mathrm{l}^{-1}$ (131\% saturation) DO. Males occupied areas with mean DO concentrations ranging from $4.3 \mathrm{ml} \mathrm{l}^{-1}$ (61\% saturation) in December to $8.2 \mathrm{ml} \mathrm{l}^{-1}$ (124\% saturation) in July. Individual crabs occupied areas with DO ranging from 3.5 to $9.0 \mathrm{ml} \mathrm{l}^{-1}$ (50 to $135 \%$ saturation).
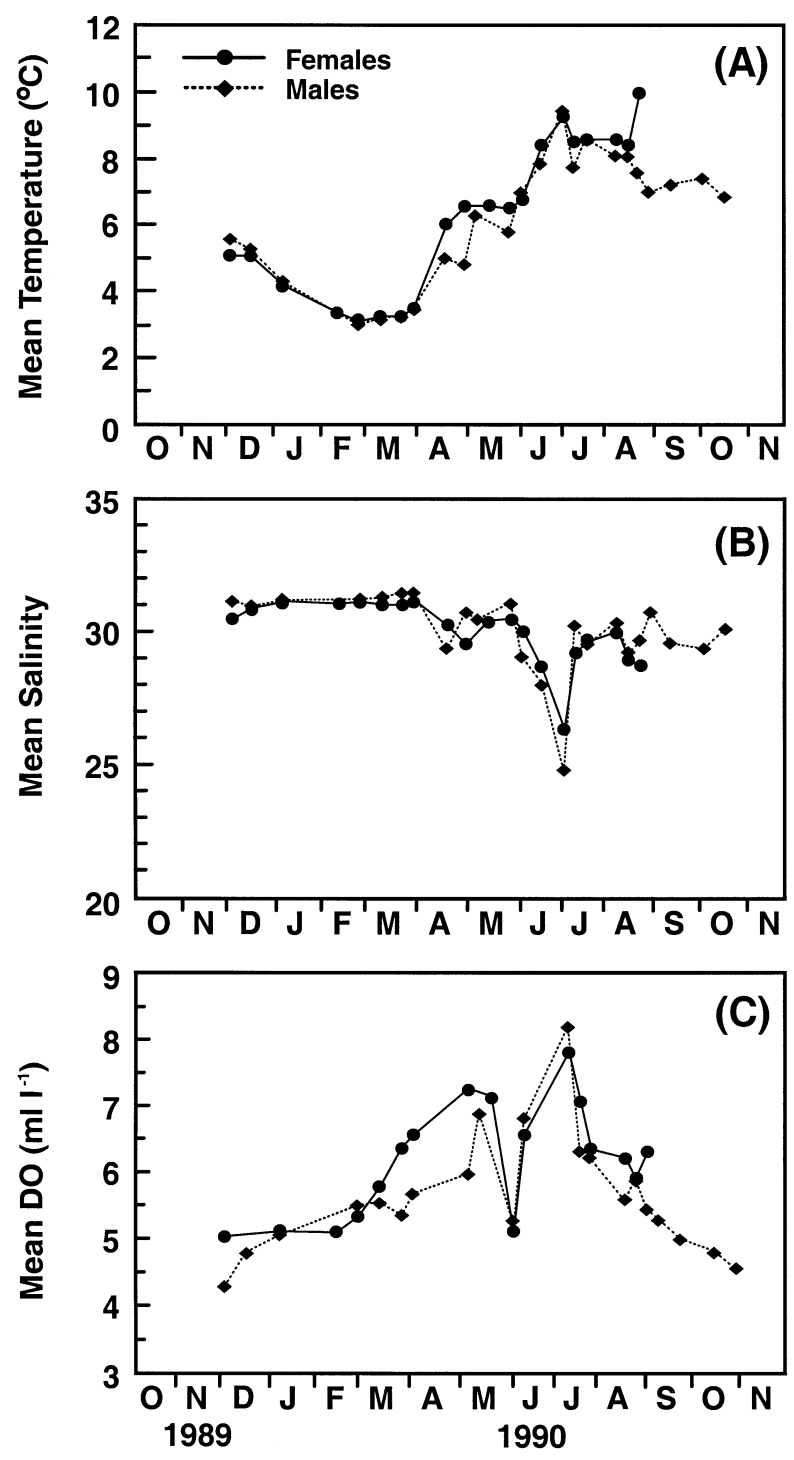

Fig. 6. (A) Mean bottom water temperature, (B) salinity, and (C) dissolved oxygen of areas occupied by female and male Cancer magister fitted with ultrasonic transmitters between November 1989 and 1990 


\section{DISCUSSION}

Despite the existence of important Cancer magister fisheries in Alaska (e.g., Alaskan harvests account for almost $50 \%$ of the total US harvest in some years: Alaska Department of Fish and Game 1990), information on movements and the timing of critical life history events of Dungeness crabs in Alaska is incomplete. Although we do not intend the data collected in this study to be comprehensive, we believe the movement and life history patterns that we infer from relatively short tracking periods (73 to $555 \mathrm{~d}$ ) are indicative for this species in southeastern Alaska.

Research on the movements and distribution of Dungeness crabs in inland waters of southeastern Alaska has been limited. Lehman \& Osborn (1970) tagged both female and male crabs in a fjord-type estuary and concluded from tag recoveries that post-larval crabs probably do not undertake extensive migrations. They attribute the limited movements to the discontinuity of appropriate habitat. Results from that study on movement and depth distribution patterns for males and females were similar to our study, except they did not observe movement by females into shallow water in spring.

Results from this study substantiate previous work on short-term movements (up to $10 \mathrm{~d}$ ) of Dungeness crabs in southeastern Alaska, which indicated that ovigerous female crabs were less active, moved shorter distances, and used fewer of the available habitats than male crabs $\left(\mathrm{O}^{\prime} \mathrm{Clair}\right.$ et al. 1990). Furthermore, we were able to confirm that ovigerous crabs use a very restricted area for much of the egg-brooding period. The restriction of egg-brooding to a small proportion $(<10 \%)$ of the total habitat at the head of Fritz Cove is strong evidence for habitat selection by ovigerous female crabs. We suspect this habitat has specific characteristics which are optimal for brooding eggs.

Compared to adult Dungeness crab populations outside southeastern Alaska, Fritz Cove crabs had very limited movements and restricted distribution. Merritt (1985) briefly summarized data from a mark and recapture program conducted on Dungeness crabs in Lower Cook Inlet, Alaska, which indicated that movement of crabs differed with geographical area. Crabs inhabiting bays appeared to have more restricted and localized movements than crabs which occupied coastal areas. Although described as localized movements, crabs in Lower Cook Inlet had estimated home ranges (52 to $667 \mathrm{~km}^{2}$ ) much larger than those we estimated for crabs in Fritz Cove.

Smith \& Jamieson (1991) studied the movement of adult Dungeness crabs in southern British Columbia, and although they described movements as non-migratory and limited, they estimated movement rates much greater than those observed in this study. They estimated rates of $419 \mathrm{~m} \mathrm{~d}^{-1}$ for females and $288 \mathrm{~m} \mathrm{~d}^{-1}$ for males compared to our measurements of 23 and $51 \mathrm{~m}$ $\mathrm{d}^{-1}$, respectively, for females and males. They monitored the movements of crabs from August through February, whereas we monitored crab movements from November through August for females and for 1 full year for males. They used beam trawling, mark and recapture, and acoustic tagging methods to infer that females moved more than males, a result that differs from that of the present study. Smith \& Jamieson (1991) found that both females and males were less active during winter, and that males retreated to deeper water in fall and winter and returned to shallow water in spring and summer; these results agree with those of the present study.

The movements of male Dungeness crabs ( $\geq 155 \mathrm{~mm}$ $\mathrm{CW}$ ) along coastal Washington were studied as part of mark and recapture study by Cleaver (1949). Males made considerable along-shore migrations averaging 18.5 to $22 \mathrm{~km}$ after 6 mo. Although most crabs moved less than $37 \mathrm{~km}, 1 \mathrm{crab}$ moved over $148 \mathrm{~km}$ in just $6 \mathrm{mo}$. Smaller crabs ( $\leq 169 \mathrm{~mm} \mathrm{CW}$ ) tended to migrate more than larger crabs.

Movements of Dungeness crabs were also studied in northern California (Gotshall 1978, Diamond \& Hankin 1985). Gotshall analyzed mark and recapture data from a multi-year study of male crabs. Movements were described as limited and crabs as resident to areas, despite moving at rates up to $740 \mathrm{~m} \mathrm{~d}^{-1}$ and straight-line distances of $60 \mathrm{~km}$ or more in a fishing season ( 1 crab moved $29 \mathrm{~km}$ in $39 \mathrm{~d}$ ). Extensive alongshore movements were made in some areas and prevailing currents were suspected as factors governing those movements. The farthest straight-line distance moved by a male in our study was $7.2 \mathrm{~km}$. Gotshall (1978) also observed the seasonal deep to shallowwater movement of males observed in our study and that of Smith \& Jamieson (1991).

Diamond \& Hankin (1985) studied the movements of adult ( $\geq 90 \mathrm{~mm} \mathrm{CW}$ ) female Dungeness crabs in northern California using mark and recapture methods. Of the females recovered that were at large for 1 full year, $27 \%$ were recovered within $2 \mathrm{~km}$ of their release site. The authors suggest that this degree of site-fidelity implies that adult females constitute highly localized stocks there. Over $40 \%$ of the females moved more than $5 \mathrm{~km}$, however, and several moved over $60 \mathrm{~km}$. They did not indicate the reproductive status (i.e., ovigerous or non-ovigerous) of the females in their study; ovigerous females tend to be less active then nonovigerous crabs (O'Clair et al. 1990). Diamond \& Hankin (1985) found no difference in female movements in relation to body size. In general, females moved inshore in spring for molting, mating, and egg extrusion, and then moved offshore in the fall to release larvae. 
Table 3. Peak timing of life history events of adult Dungeness crabs from locations throughout its range

\begin{tabular}{|c|c|c|c|c|c|c|}
\hline Location & $\begin{array}{l}\text { Female } \\
\text { ecdysis }\end{array}$ & $\begin{array}{l}\text { Male } \\
\text { ecdysis }\end{array}$ & Mating & Oviposition & Eclosion & Source \\
\hline \multicolumn{3}{|l|}{ California } & Mar to Jun & $\begin{array}{l}\text { Late Sep to } \\
\text { Nov }\end{array}$ & & $\begin{array}{l}\text { Wild (1980), } \\
\text { no data provided }\end{array}$ \\
\hline \multicolumn{3}{|l|}{ Central California } & & Oct & $\begin{array}{l}\text { Late Dec to } \\
\text { Early Feb }\end{array}$ & $\begin{array}{l}\text { Wild (1980), } \\
\text { no data provided }\end{array}$ \\
\hline \multicolumn{3}{|l|}{ N. California } & & Oct & $\begin{array}{c}\text { Jan to early } \\
\text { Mar }\end{array}$ & $\begin{array}{l}\text { Wild (1980), } \\
\text { no data provided }\end{array}$ \\
\hline \multicolumn{3}{|l|}{ N. California } & Apr \& May & & & Gotshall (1978) \\
\hline \multicolumn{3}{|l|}{ N. California } & & & Late fall & Diamond \& Hankin (1985) \\
\hline N. California & $\begin{array}{l}\text { Mid-Feb to } \\
\text { Mid-Mayb }\end{array}$ & $\begin{array}{l}\text { Late Jul to } \\
\text { Late Aug }\end{array}$ & & & $\begin{array}{l}\text { Mid-Dec to } \\
\text { Late Feb }\end{array}$ & Hankin et al. (1997) \\
\hline \multirow{2}{*}{$\begin{array}{l}\text { Coastal Washington } \\
\text { Washington }\end{array}$} & May \& Jun & Early Nov & May \& Jun ${ }^{c}$ & Early Nov & Jan to Mar & Cleaver (1949) \\
\hline & & & & & Mid-Feb & Sulkin \& McKeen (1996) \\
\hline Washington & May \& Jun & Jul to Oct & May \& Jun & & & Orensanz \& Gallucci (1988) \\
\hline \multicolumn{2}{|l|}{ British Columbia } & & & Sep to Feb & & Butler (1956) \\
\hline \multicolumn{2}{|l|}{ SE Alaska } & & & Oct \& Nov & & Shirley et al. (1987) \\
\hline SE Alaska & Jul to Sep & May to Aug & Aug \& Sep & & & $\begin{array}{l}\text { Shirley \& Shirley (1988), } \\
\text { no data provided }\end{array}$ \\
\hline SE Alaska & & Feb to May ${ }^{\mathrm{d}}$ & & Sep \& Oct & Apr & Lehman \& Osborn (1970) \\
\hline SE Alaska & Jun \& Jul & Dec to Mar & Jun to Sep ${ }^{e}$ & Aug to Oct & Apr to Jul & This study \\
\hline 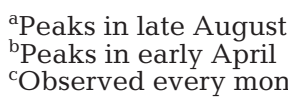 & th except Ja & & $\begin{array}{l}{ }^{\mathrm{d}} \text { Obser } \\
{ }^{\mathrm{e}} \text { Obser }\end{array}$ & $\begin{array}{l}\text { ed soft-shelle } \\
\text { ed every mon }\end{array}$ & $\begin{array}{l}\text { crabs every } n \\
\text { h except Febr }\end{array}$ & $\begin{array}{l}\text { onth except January } \\
\text { ary }\end{array}$ \\
\hline
\end{tabular}

Compared to the above studies on movements of Dungeness crabs, the adult population in Fritz Cove showed very localized movements. None of the female crabs moved further than $4.2 \mathrm{~km}$ from the head of the cove, and although several males moved outside the cove, those which did not molt and which we were able to continue monitoring, returned to the shallow-water areas of the cove in the spring. No tagged crabs moved close to the nearest established population of Dungeness crabs $9.6 \mathrm{~km}$ distant. Because of the disjunct distribution of crab populations in southeastern Alaska, and based on results of this study, limited movement of adult crabs in populations in southeastern Alaska may be more the rule than the exception. Given the limited movements and small home ranges of adult Dungeness crabs in southeastern Alaska populations, they may be a good candidate species for studying the effectiveness of marine reserves designed to protect populations from overexploitation and human disturbance.

The timing of life history events for crabs in this study occurred later in the year than in southern populations (Table 3). One notable exception was that we observed mating (i.e., crabs in a pre-copulatory embrace) pairs of Dungeness crabs in situ every month except February in northern southeastern Alaska (Stone \& O'Clair pers. obs.). Mating in Dungeness crabs is not strictly seasonal or synchronous in southeastern Alaska, although a peak in mating occurs in late summer and early fall. The timing of mating may differ between female reproductive classes. We observed pubescent females (i.e., females about to undergo their molt to maturity; <118 mm CW) mating between August and April, while larger females (>118 mm CW) were observed mating between May and December. A similar size-dependent timing for mating in female crabs was observed in northern California (Hankin et al. 1997). Our observations of mating pairs were rare, however. We have observed only 65 pairs in shallow water (intertidal to $-25 \mathrm{~m}$ ) during any time of year. One explanation for this is that mating may be more common deeper than $-25 \mathrm{~m}$. Although we did find 1 mating pair which was completely buried in sand-silt substrate, we do not know if this is common behavior. Cleaver (1949) observed mating pairs in all months except January in coastal Washington. Another difference we found in the timing of life history events was that females in Fritz Cove oviposit at about the same time of year or earlier than those in southern areas and they brood eggs for a much longer time (up to $9 \mathrm{mo}$ ). Embryonic development in the colder water $\left(3\right.$ to $\left.7^{\circ} \mathrm{C}\right)$ of southeastern Alaska should be slower than in warmer southern waters (Shirley et al. 1987).

Although Cancer magister is a weak hyperosmotic regulator and is able to tolerate lower salinity than other Cancer species (Mantel \& Farmer 1983), only 4 tagged crabs (on 6 separate occasions) were tracked into the intertidal region where salinity was often greatly reduced (21.2 in this study). Crabs moved to 
deeper water in late June, when shallow-water areas became brackish, but crabs were not inhibited from moving into shallow-water areas by the strong thermocline and halocline that developed there in spring. Movements of female red king crabs appear to be constrained by these strong clines (Stone et al. 1992). Crabs in the present study occupied areas where salinity ranged from 18.3 to 31.9 . In situ salinity ranges for adult Dungeness crabs have not been published, so we cannot compare the range observed in our study with that in other areas. Crabs in this study occupied areas with a relatively narrow range of temperatures $(2.7$ to $12.2^{\circ} \mathrm{C}$ ). Water temperatures in Fritz Cove never dropped to $1^{\circ} \mathrm{C}$, at which temperature adult female crabs held in the laboratory suffer $100 \%$ mortality after 35 d (Shirley et al. 1987).

The Fritz Cove population may be representative of most adult Dungeness crab populations inhabiting shallow embayments of the coastal fjord system of southeastern Alaska. These populations may also be geographically discrete and very localized. If such populations are dependent on larval recruitment from within to maintain the population, they may be more susceptible to local disturbances such as over-fishing, mass mortality from sea otter predation, pollution, and development. Genetic studies indicate little stock separation over much of the species' range (Soulé \& Tasto 1983), however, probably due to extensive dispersal of the larvae, which are planktonic for up to 5 mo. Genetic studies have not been conducted on discrete populations in southeastern Alaska. Until larval transport dynamics and recruitment and genetic studies are conducted, populations of adult crabs in southeastern Alaska should be managed as though they are spatially discrete.

Acknowledgements. We thank Linc Freese, Tyrus Brouillette, Ken Krieger, Blaine D. Ebberts, and Tony Chan for their assistance in the field. We also thank Mark Carls for computer assistance, and Tom Shirley, Ken Krieger, and Bruce Wing for many helpful suggestions to this manuscript. This project was funded by the Auke Bay Laboratory, Alaska Fisheries Science Center, National Marine Fisheries Service.

\section{LITERATURE CITED}

Alaska Department of Fish and Game (1990) Region 1 shellfish fisheries report to the Board of Fisheries. Alaska Department of Fish and Game, Juneau, AK

Autodesk Inc. (1988) Autocad Release 10. Oakland, California

Butler TH (1956) The distribution and abundance of early post-larval stages of the British Columbia commercial crab. Fish Res Board Can, Prog Rep Pacif Coast Stn 107: 641-646

Cleaver FC (1949) Preliminary results of the coastal crab (Cancer magister) investigation. Biol Rep 49A:47-82
DeBrosse G, Sulkin S, Jamieson G (1990) Intraspecific morphological variability in megalopae of three sympatric species of the genus Cancer (Brachyura: Cancridae). J Crustac Biol 10:315-329

Diamond N, Hankin DG (1985) Movements of adult female Dungeness crabs (Cancer magister) in Northern California based on tag recoveries. Can J Fish Aquat Sci 42: 919-926

Dinnel PA, Armstrong DA, McMillan RO (1993) Evidence for multiple recruitment-cohorts of Puget Sound Dungeness crab, Cancer magister. Mar Biol 115:53-63

Gotshall DW (1978) Northern California Dungeness crab, Cancer magister, movements as shown by tagging. Calif Fish Game 64:234-254

Hankin DG, Butler TH, Wild PW, Xue Q (1997) Does intense fishing on males impair mating success of female Dungeness crabs? Can J Fish Aquat Sci 54:655-669

Holme NA, McIntyre AD (1971) Methods for the study of marine benthos. Blackwell Scientific Publications, Oxford

Jensen GC, Armstrong DA (1987) Range extensions of some northeastern Pacific Decapoda. Crustaceana 52: 215-217

Kondzela CM, Shirley TC (1993) Survival, feeding, and growth of juvenile Dungeness crabs from southeastern Alaska reared at different temperatures. J Crustac Biol 13: 25-35

Largier JL (1992) Tidal intrusion fronts. Estuaries 15:26-39

Lehman C, Osborn O (1970) Dungeness crab research. Completion report, Alaska Department of Fish Game, Juneau, AK

Mantel LH, Farmer LL (1983) Osmotic and ionic regulation. In: Mantel LH (ed) The biology of Crustacea. Vol. 5. Academic Press Inc., New York, p 53-161

Merritt MF (1985) The Lower Cook Inlet Dungeness crab fishery from 1964-1983. In: Proceedings of the Symposium on Dungeness Crab Biology and Management. University of Alaska, Fairbanks, Alaska, p 85-95 (Sea Grant Coll Prog Rep No. 85-3)

O'Clair CE, Stone RP, Freese JL (1990) Movements and habitat use of Dungeness crabs and the Glacier Bay fishery. In: Milner AM, Wood JD Jr (eds) Proceedings of the Second Glacier Bay Science Symposium. US Department of the Interior, National Park Service, Alaska Regional Office, Anchorage, AK, p 74-77

Orensanz JM, Gallucci VF (1988) Comparative study of postlarval life-history schedules in four sympatric species of Cancer (Decapoda: Brachyura: Cancridae). J Crustac Biol 8:187-220

Powell GC (1964) Fishing mortality and movements of adult male king crabs, Paralithodes camtschatica (Tilesius), released seaward from Kodiak, Alaska. Trans Am Fish Soc 93:295-300

Shirley SM, Shirley TC (1988) Appendage injury in Dungeness crabs, Cancer magister, in Southeastern Alaska. Fish Bull (Wash DC) 86:156-160

Shirley SM, Shirley TC, Rice SD (1987) Latitudinal variation in the Dungeness crab, Cancer magister: zoeal morphology explained by incubation temperature. Mar Biol 95: 371-376

Smith BD, Jamieson GS (1991) Movement, spatial distribution, and mortality of male and female Dungeness crab Cancer magister near Tofino, British Columbia. Fish Bull (Wash DC) 89:137-148

Soulé M, Tasto RN (1983) Stock identification studies on the Dungeness crab, Cancer magister. Fish Bull Calif 172: $39-42$

Stone RP, O'Clair CE, Shirley TC (1992) Seasonal migration 
and distribution of female red king crab in a southeast Alaskan estuary. J Crustac Biol 2:546-560

Sulkin SD, McKeen GL (1996) Larval development of the crab Cancer magister in temperature regimes simulating outercoast and inland-water habitats. Mar Biol 127:235-240

US Department of the Interior (1966) Oceanographic and related water quality studies in southeastern Alaska, August, 1965. Federal Water Pollution Control Administration, Portland, OR

Editorial responsibility: Otto Kinne (Editor),

Oldendorf/Luhe, Germany
Wallace MM, Pervit LJ, Havatum AR (1949) Contribution to the biology of the king crab ( $P$. camtschatica). US Fish Wildl Serv Fish Wildl Leafl 34:1-50

Wild PW (1980) Effects of seawater temperature on spawning, egg development, hatching success, and population fluctuations of the Dungeness crab, Cancer magister. CALCOFI Rep 21:115-120

Worton BJ (1987) A review of models of home range for animal movements. Ecol Model 38:277-298

Submitted: June 27, 2000; Accepted: August 24, 2000

Proofs received from author(s): April 3, 2001 